\title{
PEMAKNAAN MAHASISWA TERHADAP SIMBOL PANCASILA SEBAGAI IDENTITAS BANGSA
}

\author{
Nerissa Erviana Hadianti Kustoyo ${ }^{1}$, Siti Zunariyah ${ }^{2}$ \\ Program Studi Sosiologi Fakultas Ilmu Sosial dan Politik \\ Universitas Sebelas Maret Surakarta Indonesia \\ Email ${ }^{1}$ : nerissaervi@gmail.com, Email²: zunariyah@gmail.com
}

\begin{abstract}
The purpose of this study is to: To find out the meaning of the Pancasila symbol in the souls of students, To find out the practice of Pancasila values on student life, To know students in responding to Pancasila towards the meaning of a nation's identity.This study uses qualitative methods through in-depth interview techniques, and direct observation. Primary data obtained from interviews. The sampling of this study was through purposive sampling. The results of this study are: The meaning of students towards Pancasila based on Max Weber's theory of action can be categorized into rational values (werk rational) which are based on divine values, mutual respect, adab, and humanity, and the value of justice. Besides affective actions based on the love of water and unity, The application of Pancasila into the daily lives of students can be categorized into rational acts of values based on mutual respect and do not differentiate between religious adherents, values unity and value of deliberation to reach consensus; affective actions based on the love of the motherland; instrumental rational actions based on means of respect and tolerance to achieve peace and unity, and means of association, participation in activities in society, Student attitudes towards Pancasila as a nation's identification are categorized into rational acts of value based on values respect for differences, values of togetherness or unity; instrumental rational value actions (zwerk rational) which are based on means of deliberation to reach consensus, the struggle to achieve goals; Affective action that is based on the love of the motherland.
\end{abstract}

Keywords: Meaning, Student, Pancasila, Action.

Abstrak: Tujuan penelitian ini adalah untuk : Mengetahui pemaknaan arti symbol Pancasila di dalam jiwa para mahasiswa, Mengetahui pengamalan nilai - nilai Pancasila pada kehidupan mahasiswa, Mengetahui mahasiswa dalam menyikapi Pancasila terhadap makna identitas suatu bangsa.Penelitian ini menggunakan metode kualitatif melalui teknik wawancara mendalam, dan observasi langsung. Data primer diperoleh dari hasil wawancara. Pengambilan sampel penelitian ini adalah melalui purposive sampling.

Hasil penelitian ini adalah: Pemaknaan mahasiswa terhadap Pancasila berdasarkan teori tindakan Max Weber dapat dikategorikan ke dalam jenis tindakan rasional nilai (werk rational) yang didasarkan pada nilai ketuhanan, saling menghargai, adab, dan kemanusiaan, serta nilai keadilan. Selain itu tindakan afektif (affectif action) yang didasarkan pada rasa cinta tanh air dan persatuan, Pengamalan Pancasila ke dalam kehidupan sehari-hari mahasiswa dapat dikategorikan ke dalam tindakan rasional nilai yang didasarkan pada saling menghormati dan tidak membedakan antar pemeluk agama, nilai persatuan dan nilai musyawarah untuk mufakat; tindakan afektif yang didasarkan pada rasa cinta tanah air; tindakan rasional instrumental yang didasarkan pada sarana menghormati dan tenggang rasa untuk mencapai damai dan persatuan, dan sarana pergaulan, partisipasi dalam kegiatankegiatan dalam masyarakat, Sikap mahasiswa terhadap Pancasila sebagai identitasi suatu bangsa dikategorikan ke dalam tindakan rasional nilai yang didasarkan pada nilai menghormati perbedaan, nilai kebersamaan atau persatuan; tindakan nilai rasional instrumental (zwerk rational) yang didasarkan pada sarana musyawarah untuk mufakat, 
perjuangan untuk mencapai tujuan; tindakan afektif (affectif action) yang didasarkan pada rasa cinta tanah air.

Kata kunci: Pemaknaan, Mahasiswa, Pancasila, Tindakan.

\section{PENDAHULUAN}

Pancasila merupakan suatu ideologi dasar bangsa Indonesia di dalam berpedoman dalam kehidupan berbangsa dan bernegara. Lain daripada itu kalau proklamasi kemerdekaan itu kita pandang sebagai realisasi dari ikrar pemuda pada tahun 1928 maka kedudukan Pancasila itu mengetengahkan prinsip kemerdekaan dengan landasan satu bangsa, satu negara dan satu bahasa. Pancasila yang pada waktu diciptakan untuk mendukung kehidupan berbangsa dan bernegara adalah selaras dengan ikrar pemuda, sedang untuk pemanfaatan serta pengembangan bahasa tidak perlu disebut secara eksplisit Pancasila sebagai landasannya. Diterimanya Pancasila sebagai dasar falsafah untuk hidup berbangsa dan bernegara adalah tepat dan amat bermanfaat oleh karena dengan demikian menjadi jelas adanya satu falsafah yang melandasi negara kita yang baru bangkit dalam kemerdekaan pada waktu itu. (Oetojo Oesman dan Alfan, 1992 : 169 ).

Berbeda dengan bangsa-bangsa lain, bangsa Indonesia mendasarkan pandangan hidupnya dalam bermasyarakat, berbangsa, dan bernegara pada suatu asas kultural yang dimiliki dan melekat pada bangsa itu sendiri. Nilainilai kenegaraan dan kemasyarakatan yang terkandung dalam sila-sila Pancasila bukan hanya hasil konseptual seseorang saja, melainkan juga hasil karya besar bangsa Indonesia sendiri, yang diangkat dari nilai-nilai kultural yang dimiliki oleh bangsa Indonesia sendiri melalui proses refleksi filosofis para pendiri negara (Kaelan, 2000: 13). Namun, dalam kenyataannya saat ini nilai - nilai Pancasila mulai luntur dalam kehidupan bermasyarakat, berbangsa dan bernegara. Menurut (Wahab, 2011 : 81) pengimplementasian Pancasila diklasifikasikan ke dalam beberapa kelompok, sebagai berikut:

1. Ada sekelompok masyarakat yang tahu Pancasila dan mengamalkan dalam kehidupan sehari hari.

2. Ada sekelompok masyarakat yang tahu Pancasila tetapi tidak / belum mengamalkan dalam kehidupan sehari hari.

3. Ada sekelompok masyarakat yang tidak tahu Pancasila dan tidak / belum mengamalkan dalam kehidupan sehari - hari.

4. Ada sekelompok masyarakat yang tidak tahu Pancasila tetapi mengamalkan dalam kehidupan sehari - hari.

Dan disini hendaknya mahasiwa yang sebagai agent of change bertindak sebagai generasi yang terus mengamalkan akan pengetahuan dan pemahaman Pancasila dalam kehidupannya karena mahasiwa sebagai tolak ukur bahwa seseorang yang dianggap berpendidikan. Karena bangsa yang pintar dan berbudi luhur bukan hanya seseorang yang bisa mencapai tingkat akademik yang tinggi, namun nilai Pancasila yang diamalkan dalam kehidupan dan identitas yang didapatkan dari Pancasila itu lah yang menjadi tolak ukur bahwa seorang warga negara itu dikatakan seorang warga Indonesia yang sesungguhnya. Bukan dimulut tetapi di hati dan di amalkan dalam kehidupannya.

\section{METODOLOGI}


Penelitian ini menggunakan metode penelitian deskriptif dan pendekatan kualitatif yang bertujuan untuk menggambarkan secara tepat fenomena yang terjadi secara sistematis, aktual, dan akurat sesuai dengan fakta yang ada dengan mengumpulkan data, menjelaskan secara obyektif dalam arti hasil penelitian ini lebih menekankan gambaran mengenai Pemaknaan Mahasiswa Terhadap Simbol Pancasila Sebagai Identitas Bangsa di lokasi penelitian ini dilakukan di Universitas Sebelas Maret .Subyek dari penelitian ini adalah para mahasiswa maupun mahasiswi yang berkuliah di UNS dengan prodi dan angkatan kuliah yang beragam. Obyek dari penelitian ini adalah Pemakanaan Mahasiswa Terhadap Pancasila. Penelitian ini menggunakan teknik purposive sampling dengan menggunakan metode pengumpulan data indept interview, observasi dan dokumentasi. Analisis data yang digunakan adalah analisis interaktif, yaituReduksi data (proses pemilihan, pemusatan perhatian pada penyederhanaan, dan transformasi data kasar yang muncul dari catatan-catatan tertulis di lapangan.), Sajian data (deskripsi dalam bentuk narasi yang dapat membuat sebuah kesimpulan penelitian yang dilakukan.), dan penarikan kesimpulan (penyimpulan berasal dari rangkuman dan olahan data yang berupa gejala dan kasus yang ada di lapangan). Dalam teknik validitas data, penelitian ini menggunakan teknik triangulasi sumber data. Teknik triangulasi anta rsumber data, teknik pengumpulan data, dan pengumpulan data yang dalam hal terakhir ini peneliti akan berupaya mendapatkan rekan atau pembantu dalam penggalian data dari teman - teman yang saling berkaitan dan kenal dengan subjek yang mampu membantu setelah diberi penjelasan.

\section{HASIL DAN PEMBAHASAN}

\section{a. Makna Pancasila berdasarkan Sila-nya}

Pancasila merupakan simbol negara Indonesia. Akan tetapi sebagai sebuah simbol, Pancasila memiliki makna yang harus ditafsir atau diintepretasikan sehingga siapapun dapat mengambil pengertian atau arti dari simbol Pancasila tersebut. Mengetahui arti Pancasila sangat penting karena nilai-nilai yang terkandung di dalam Pancasila selanjutnya dapat diimplementasikan ke dalam kehidupan sehari-hari, dalam konteks berkehidupan berbangsa dan bernegara.

Makna sila pertama Pancasila menurut para mahasiswa adalah berkaitan dengan ketuhanan dan ajaran-ajaran agama. Akan tetapi kepercayaan atau agama yang ada di Indonesia sangat beragam, sehingga setiap individu mempercayai atau meyakini Tuhan dan agama yang dianut tetapi pada saat yang sama harus menghargai kepercayaan dan agama orang lain. Apabila dikaitkan dengan teori tindakan yang dikemukakan Weber, maka dapat dipahami bahwa pandangan mahasiswa dalam memaknai sila Ketuhanan Yang Maha Esa dikategorikan sebagai tindakan yang berorientasi nilai (Werk Rational). Tindakan semacam ini lebih mengutamakan nilai-nilai tertentu dibanding sarana-sarana. (Campbell, 1994: 208210). Hal tersebut tampak pada suatu nilai, yaitu nilai keagamaan atau ketuhanan. Nilai dianggap lebih penting sehingga jadi prioritas atau pertimbangan utama dalam melakukan tindakan atau perilaku.

Makna sila kedua Pancasila menurut para mahasiswa adalah bahwa manusia sudah seharusnya memiliki adab yang tinggi dan meningkatkan nilai-nilai kemanusiaan. Dengan begitu manusia tidak akan merendahkan manusia yang lainnya. Pandangan mahasiswa berkaitan dengan makna sila kedua dapat dipahami sebagai pandangan yang berorientasi nilai atau werk rational. Hal tersebut dimungkinkan karena mahasiswa beranggapan bahwa saling menghargai merupakan sebuah nilai penting yang perlu diperjuangkan untuk tujuan tertentu dalam konteks bermasyarakat. 
Makna sila ketiga Pancasila menurut para mahasiswa adalah bahwa makna persatuan ditempatkan sebagai sesuatu yang penting dalam konteks berbangsa dan bernegara. Hal ini memungkinkan karena Indonesia terdiri dari bermacam ras, suku, bahasa, agama sehingga tanpa adanya rasa persatuan Indonesia rentan terjadi perpecahan. Dengan demikian dapat dikatakan bahwa dalam memaknai sila Persatuan Indonesia, pandangan mahasiswa lebih menggunakan perasaan atau emosi. Menurut Weber, tindakan semacam itu dapat dikategorikan ke dalam tindakan afektif, yaitu tingkah laku yang didominasi oleh perasaan. (Campbell, 1994: 208-210).

Makna sila keempat Pancasila menurut para mahasiswa adalah bahwa dalam berbagai persoalan yang muncul dalam kehidupan, baik keluarga, masyarakat dan negara haruslah lebih mementingkan kepentingan umum dan bukan individual. Penyelesaian permasalahan yang ada harus selalu diselesaikan melalui musyawarah untuk mencapai mufakat. Dengan demikian dapat dikatakan bahwa pandangan mahasiswa mengenai sila keempat lebih berorientasi pada nilai, yaitu musyawarah dalam mencapai mufakat. Oleh karena itu, pemaknaan mahasiswa terhadap sila keempat dikategorikan sebagai tindakan yang berorientasi nilai. Menurut pandangan Weber, tindakan yang berorientasi nilai dapat digolongkan ke dalam tindakan rasional nilai atau werk rational, yaitu tindakan yang berorientasi kepada nilai daripada sarana-sarana dalam mencapai suatu tujuan. (Campbell, 1994: 208-210). .

Makna sila kelima Pancasila menurut para mahasiswa adalah bahwa keadilan merupakan sebuah keniscayaan dalam hidup berbangsa dan bernegara. Keadilan tersebut harus tercermin dari kebijakan-kebijakan yang diambil oleh pemerintah, walaupun keadilan bukan berarti sama rata. Atau dengan kata lain kebijakan harus berasaskan Pancasila, sehingga diharapkan keadilan tersebut akan merata bagi seluruh rakyat Indonesia. dengan demikian dapat dipahami bahwa pemaknaan mahasiswa tentang sila Keadilan Sosial Bagi Seluruh Rakyat Indonesia lebih berorientasi pada niai. Hal tersebut tampak pada ungkapan bahwa adil atau keadilan merupakan suatu keharusan, yang merupakan sebuah nilai penting dan mutlak dalam mencapai tujuan tertentu, seperti kesejahteraan sosial. Pandangan yang berorientasi nilai oleh Weber disebut sebagai tindakan rasional nilai atau werk rational. (Campbell, 1994: 208-210).

Makna simbol Pancasila di atas mengandung berbagai macam unsur atau nilai seperti keagamaan, moral, norma, dan lingkungan. Hal tersebut sebagaimana yang diungkapkan Triguna (2000: 35) yang memaparkan bahwa ada empat peringkat simbol, yaitu (1) simbol konstruksi yang berbentuk kepercayaan dan biasanya merupakan inti dari agama (2) simbol evelausi berupa penilaian moral yang sarat dengan nilai, norma dan aturan; (3) simbol kognisi berupa pengetahuan yang dimanfaatkan manusia untuk memperoleh pemgetahuan tentang realitas dan keteraturan agar manusia lebih memahami lingkungannya; (4) simbol ekspresi berupa pengungkapan perasaan. Keempat pembagian simbol itu bisa dilihat secara hierarki vertikal- transenden menyebabkan simbol konstruktif merupakan simbol yang paling hakiki.

\section{b. Pengamalan Pancasila ke dalam kehidupan sehari-hari}

Berdasarkan beberapa ungkapan di atas, dapat dikatakan bahwa tindakan yang dilakukan oleh para mahasiswa dalam rangka menafsir dan mengamalkan sila pertama juga didasarkan pada simbol Pancasila yang mereka interpretasikan tersebut. Tindakan mahasiswa sebagai implementasi sila pertama tersebut dapat dikatakan sebagai tindakan sosial karena berkaitan dengan lingkungan dan perilaku orang lain. Hal ini seperti yang diungkapkan oleh Wirawan (2012: 83), bahwa seseorang dalam bertindak bukan sekedar melaksanakannya tetapi juga menempatkan diri dalam lingkungan, berfikir dan perilaku orang lain. Konsep 
pendekatan ini lebih mengarah pada suatu tindakan bermotif pada tujuan yang hendak dicapai atau in order to motive.

Pengamalan sila Ketuhanan Yang Maha Esa oleh mahasiswa dapat dikategorikan sebagai tindakan rasional nilai (werk rational), karena lebih mengedepankan nilai daripada sarana-sarana yang lain. Hal tersebut sejalan dengan pandangan Weber yang menjelaskan bahwa nilai menjadi pertimbangan utama dalam melakukan suatu tindakan. (Campbell, 1994: 208-210).

Berdasarkan beberapa pernyataan narasumber di atas, dapat diambil pengertian bahwa makna sila kemanusiaan yang adil dan beradab oleh para mahasiswa adalah menghormati sesama, bersikap tenggang rasa terhadap orang lain serta berusaha untuk tidak merugikan orang lain. Tindakan yang merupakan pengamalan dari sila kedua Pancasila tersebut juga didasarkan pada pertimbangan pada tingkah laku orang lain. Artinya, sikap tenggang rasa, saling menghormati tersebut merupakan sarana atau alat untuk mencapai tujuan, yaitu terciptanya masyarakat yang damai dan bersatu. Dengan demikian dapat dikatakan bahwa tindakan mahasiswa yang berkaitan dengan implementasi terhadap sila kedua dikategorikan sebagai rasional instrumental atau zwerk rational. (Campbell, 1994: 208-210). Weber juga menyebutkan bahwa "tindakan bersifat sosial sejauh, berdasarkan atas makna subjektif yang dilekatkan padanya oleh individu yang bertindak, tindakan itu merupakan perhitungan tingkah laku orang-orang lain dan dengan cara itu pelaksanaannya terarah." (dalam Eriyanto, 2002: 13).

Implementasi terhadap sila Persatuan Indonesia dapat dikategorikan ke dalam tindakan rasional nilai atau werk rational. Tindakan tersebut lebih mementingkan nilai atau nilai menjadi sesuatu yang penting untuk dikejar dan menjadi pertimbangan dalam melakukan suatu tindakan. Nilai tersebut adalah persatuan yang dapat dicapai antara lain dengan menumbuhkan kesadaran untuk tidak membeda-bedakan satu dengan yang lainnya, beradaptasi di lingkungan yang baru dan lain sebagainya. Semua itu dilakukan dlaam rangka untuk menjaga nilai persatuan.

Implementasi terhadap sila keempat dengan menyeimbangkan antara hak dan kewajiban, mengutamakan musyawarah dalam mencapai mufakat. Artinya, dalam rangka mencapai tujuan yaitu kehidupan masyarakat yang lebih baik, harus menyeimbangkan hak dan kewajiban serta mendahulukan musyawarah dalam rangka mencapai mufakat. Tindakan semacam ini dapat dikatakan sebagai tindakan yang berorientasi nilai atau werk rational, yaitu model tindakan yang mengutamakan nilai untuk mencapai tujuan tertentu. (Campbell, 1994: 208-210). Berkaitan dengan hal tersebut, Soekanto (2002: 37-38) menyebutkan bahwa tindakan sosial merupakan suatu tindakan yang dilakukan manusia demi suatu tujuan yang jelas. Artinya, tindakan sosial itu memiliki arti subjektif dari pelaku tindakan dan terarah kepada orang lain. Pelaku melakukan sesuatu karena ada suatu orientasi yang hendak dicapai. Dengan demikian, tidaklah mudah untuk memahami makna dari suatu tindakan sosial, sebab hanya pelakulah yang sadar akan tindakannya.

Implementasi sila keadilan sosial bagi seluruh rakyat Indonesia dipahami sebagai tindakan rasional instrumental atau zwerk rational, yaitu tindakan yang menggunakan alat atau sarana tertentu dalam meraih suatu tujuan. (Campbell, 1994: 208-210). Hal tersebut tampak pada penggunaan sarana berupa pergaulan, masuk ke dalam organisasi seperti karang taruna, partisipasi dalam kegiatan-kegiatan tertentu dalam rangka untuk mengambangkan keadilan. 


\section{Sikap mahasiwa terhadap Pancasila sebagai identitas bangsa}

Beberapa sikap mahasiswa terhadap sila pertama sebagai salah satu simbol dari Pancasila adalah dengan tidak membedakan agama dan kepercayaan yang dianut oleh orang lain serta saling menghormatinya. Hal tersebut merupakan cerminan dari nilai-nilai sosial budaya Indonesia yang memiliki bermacam-macam ras, suku, agama, dan bahasa akan tetapi tidak menimbulkan konflik dan perpecahan. Dengan demikian dapat dikatakan bahwa sikap mahasiswa terhadap sila pertama dikategorikan dalam tindakan yang berorientasi nilai (werk orientasi), yaitu tindakan yang berorientasi terhadap suatu nilai. (Campbell, 1994: 208-210). Dalam konteks ini nilai tersebut antara lain saling menghormati walaupun berbeda dalam agama, suku, ras, dan lain sebagainya demi terciptanya persatuan dan kesatuan bangsa.

Sikap mahasiswa mengenai sila kemanusiaan yang adil dan beradab diwujudkan dengan menumbuhkan kisaran adanya perbedaan-perbedaan pendapat yang ada tetapi tetap saling menghargai dan menghormati perbedaan tersebut. Seseorang tidak bisa memaksakan kehendak terhadap orang lain agar mengikuti pendapatnya. Sikap tersebut juga merupakan manifestasi dari upaya menjaga persatuan dan meredam munculnya konflik. Kerukunan merupakan salah satu ciri budaya bangsa Indonesia. Dengan demikian dapat dikatakan bahwa tindakan atau sikap mahasiswa berkaitan dengan sila kedua dikategorikan sebagai tindakan yang berorientasi nilai (werk orientasi). (Campbell, 1994: 208-210). Hal ini tampak pada sikap atau perilaku yang mengutamakan nilai kebersamaan atau persatuan melalui sikap untuk tidak egois, tenggang rasa, serta membantu sesama terutama bagi yang membutuhkan.

Sikap mahasiswa terkait dengan sila persatuan Indonesia diwujudkan dengan adanya kesadaran mengenai keragaman yang dimiliki bangsa Indonesia yang notabene terdiri dari beribu-ribu pulau dengan beragam ras, suku, agama dan bahasa. Sikap atau tindakan mahasiswa berkaitan dengan sila ketiga tersebut dikategorikan sebagai tindakan rasional yang berorientasi nilai (werk rational). (Campbell, 1994: 208-210). Sikap yang ditunjukkan dengan berhati-hati dalam berbicara, berbuat dan bersikap agar tidak melukai perasaan orang lain, merendahkan budaya lain yang ada di Indonesia, berhati-hati dalam menggunakan media sosial bertujuan agar tidak memicu perpecahan.

Sikap terhadap nilai sila kerakyatan yang dipimpin oleh hikmat dalam permusyawaratan perwakilan adalah diwujudkan dengan mengutamakan musyawarah dalam setiap menyelesaikan permasalahan yang ada. Musyawarah, seperti halnya gotong royong merupakan budaya bangsa Indonesia. Musyawarah sarana atau 'alat' dalam mencapai tujuan, yaitu mufakat. Dengan demikian dapat dikatakan bahwa sikap mahasiswa terhadap sila keempat dikategorikan sebagai tindakan rasionalitas instrumental, yaitu suatu tindakan yang dilakukan seseorang berdasarkan atas pertimbangan dan pilihan sadar yang berhubungan dengan tujuan tindakan tersebut dan ketersediaan alat yang digunakan untuk mencapainya. (Campbell, 1994: 208-210).

Sikap mahasiswa terhadap sila kelima lebih didasarkan pada pertimbangan adanya sarana dalam meraih tujuan. Perjuangan merupakan sarana atau 'alat' untuk mencapai tujuan yaitu meraih hidup yang diharapkan atau diimpikan. Dengan demikian dapat mengerti bahwa tindakan mahasiswa tersebut dikategorikan sebagai tindakan rasional instrumental (zwerk rational), yaitu tindakan yang menggunakan sarana atau alat dalam mencapai tujuannya. (Campbell, 1994: 208-210).

Sikap mahasiswa terhadap sila kelima lebih berorientasi pada perasaan atau emosional. Mahasiswa berpandangan bahwa mengikuti gaya hanya berdasarkan insting atau naluri semata. Dengan demikian dapat dipahami bahwa tindakan tersebut merupakan tindakan afektif (affectif action) berdasarkan teori Weber. 
Ungkapan yang dipaparkan mahasiswa di atas menunjukkan bahwa sikap mahasiswa terhadap sila keadilan sosial bagi seluruh rakyat Indonesia dikategorikan sebagai tindakan afektif atau affeectual action. Tindakan tersebut lebih didominasi oleh perasaan atau emosi. Hal tersebut tampak pada rasa cinta terhadap apa yang dikerjakan serta dorongan untuk mengapresiasi karya orang lain. Tindakan mahasiswa dapat dikategorikan sebagai tindakan rasional nilai. Hal tersebut tampak pada upaya menghargai orang lain dnegna memberikan apresiasi serta dorongan atau motivasi agar orang tersebut tetap semangat dalam berkarya atau berjuang meraih cita-citanya.

Sikap mahasiswa terhadap sila keadilan sosial bagi seluruh rakyat Indonesia diwujudkan dalam menghargai karya orang lain serta sikap mempertahankan kepribadian bangsa walaupun tetap mengikuti perkembangan jaman misalnya dengan mengikuti gaya pakaian yang sedang ngetren. Tindakan tersebut dapat dipahami sebagai tindakan rasional nilai karena lebih mengutamakan nilai dalam melakukan sebuah tindakan untuk mencapai tujuan tertentu yaitu, menghargai karya anak bangsa.

\section{KESIMPULAN}

Berdasarkan hasil penelitian dan pembahasan yang sudah diuraikan di atas, maka dapat disimpulkan bahwa Pemaknaan mahasiswa terhadap Pancasila berdasarkan teori tindakan Max Weber dapat dikategorikan ke dalam jenis tindakan rasional nilai (werk rational) yang didasarkan pada nilai ketuhanan, saling menghargai, adab, dan kemanusiaan, serta nilai keadilan. Selain itu tindakan afektif (affectif action) yang didasarkan pada rasa cinta tanh air dan persatuan. Pengamalan atau implementasi Pancasila ke dalam kehidupan sehari-hari mahasiswa dapat dikategorikan ke dalam tindakan rasional nilai yang didasarkan pada saling menghormati dan tidak membedakan antar pemeluk agama, nilai persatuan dan nilai musyawarah untuk mufakat; tindakan afektif yang didasarkan pada rasa cinta tanah air; tindakan rasional instrumental yang didasarkan pada sarana menghormati dan tenggang rasa untuk mencapai damai dan persatuan, dan sarana pergaulan, partisipasi dalam kegiatankegiatan dalam masyarakat. Sikap mahasiswa terhadap Pancasila sebagai identitasi suatu bangsa dikategorikan ke dalam tindakan rasional nilai yang didasarkan pada nilai menghormati perbedaan, nilai kebersamaan atau persatuan; tindakan nilai rasional instrumental (zwerk rational) yagn didasarkan pada sarana musyawarah untuk mufakat, perjuangan untuk mencapai tujuan; tindakan afektif (affectif action) yang didasarkan pada rasa cinta tanah air.

\section{DAFTAR PUSTAKA}

Alex, Sobur. 2015. Analisis Teks Media : Suatu Pengantar Analisis Wacana, Analisis Semiotika, dan Analisis Framing. Bandung : Remaja Rosdakarya.

Alwi, Mahmud. 2016. "Aktualisasi Nilai-nilai Sila Pancasila dalam Pengembangan Kurikulum PAI di SMP Negeri 9 Yogyakarta." Skripsi. Yogyakarta: Jurusan Pendidikan Agama Islam Fakultas Ilmu Tarbiyah dan Keguruan UIN Sunan Kalijaga Yogyakarta, 2016.

Astuti, Desta Ariyani. 2010. "Pemaknaan Dosen Terhadap Gaya Pakaian Kuliah Mahasiswa FISIP UNS”. Skripsi. Fakultas Ilmu Sosial Dan Ilmu Politik Universitas Sebelas Maret Surakarta.

Banner, P. 1985. Quality of Life: A Phenomenological Perspective on Explanation, Prediction, and Understanding in Nursing Science. Advances in Nursing Science, 8 (1) pp 1-14. 
Cambell, Tom.1994. Tujuh Teori Sosial Sketsa Penilaian dan Perbandingan. Yogyakarta: Kansisus.

Craib, Lain. 1992. Teori-Teori Sosial Modern: Dari Pasons sampai Habermas Jakarta: Rajawali Pers.

Eriyanto. 2002. Analisis Framing (Konstruksi, Ideologi, Politik Media). Yogyakarta: Lkis.

Handerson, A.M. dan Parsons, Talcot (ed). 1964. Max Weber: The Theory of Social and Economic Organization. New York: The Free Press.

Hariyono. 2014. Ideologi Pancasila Roh Progresif Nasionalisme Indonesia. Malang: Intans Publishing.

Hutahuruk. M, SH. 1984. Gelora Nasionalisme Indonesia. Jakarta : Elangga.

Kaelan, 2000. Pendidikan Pancasila. Yogyakarta : Paradigma.

Kinseng, Rilus A. 2017. Struktugensi: Sebuah Teori Tindakan Structugency: A Theory of Action. Sodality: Jurnal Sosiologi Pedesaan Agustus 2017, hal 127-137

Martoredjo, Nikodemus Thomas. 2016. Building Character Through Pancasila Values To Sovereign Nation. HUMANIORA Vol. 7 No.1 January 2016: 116-121

Mohamad Na'im. 2012. The Role Of The Appreciation Of History Education: The Internalization Of Pancasila Ideology And Religious Values On Creating The Nationalism Attitude. HISTORIA: International Journal of History Education, Vol. XIII, No. 2 (December 2012).

Oesman Oetodjo dan Alfian. 1992. Pancasila Sebagai Ideologi Dalam Berbagai Bidang Kehidupan Bermasyarakat, Berbangsa dan Bernegara. Jakarta: BP- 7.

Olson, G Keith. 1984. Counseling Teenagers, 5 thed. Colorado: Thom Schultz Publications, Inc.

Rahayu Sri Ani. 2013. Pendidikan Pancasila \& Kewarganegaraan(PPKn). Jakarta: Bumi Aksara

Saman, Florianus Maria Joni.2016. Veerstehen Sebagai Metode Memahami Makna Tindakan Sosial Menurut Max Weber. Majalah Ilmiah Mahasiswa, Rajawali, Tahun XII, No 1, Januari 2016.

Santrock, John W. 2002. Adolescene Perkembangan Remaja. Jakarta : Erlangga.

Siregar, Eddie, Drs, M.Si. 2012. Empat Pilar Kehidupan Berbangsa dan Bernegara. Jakarta : Sekretariat Jenderal MPR RI.

Supraja, Muhammad. 2012. Alfred Schutz: Rekonstruksi Teori Tindakan Max Weber Jurnal Pemikiran Sosiologi Volume 1 No.2, November 2012

Sutoyo. 2011. Pendidikan Kewarganegaraan Untuk Perguruan Tinggi, Yogyakarta: Graha Ilmu

Titib, I Made. 2001. Teologi \& Simbol - Simbol Praktis Kehidupan. Surabaya: Paramita.

Triguna, Ida Bagus Gede Yudha. 2000. Teori Tentang Simbol. Denpasar : Widya Darma. Bandung. Alfabeta.

Weber, Max, 1968. Economy and Society. Vol 1. (Wirschaft and Gesselschaft) Los Angeles: University of California Press Berkeley.

Weber, Max. 1946. Sosiologi, (judul asli: From Max Weber: Essays in Sosiology, Oxford University Press. diterjemahkan oleh Noorkholis dan Tim Penerjemah Promothea, Yogyakarta: Pustaka Pelajar, 2006.

Weber, Max. 1968. Economy and Society, vol. 1 (judul asli: Wirtschaft and Gesselschaft)t diterjemahkan oleh Guenter Roth dan Claus Wittich (Los Angeles: University of California Press Berkeley, 1968),

Yudistira Aktualisasi dan Implementasi Nilai-Nilai Pancasila dalam Menumbuh Kembangkan Karakter Bangsa. Seminar Nasional Hukum Volume 2 Nomor 1 Tahun 2016, 421-43 